\title{
COMMENTS
}

\section{Disparate Impact and Subjective Employment Criteria under Title VII}

Title VII of the Civil Rights Act of 1964 forbids discrimination in employment on the basis of race, color, religion, sex, or national origin. The legislative history of the statute indicates that when an employment practice has a sufficiently adverse impact on members of a protected class, intent to discriminate is not a required element of a Title VII violation. Accordingly, courts have allowed employees to challenge the "disparate impact" of a particular requirement or step in an employment or promotion process, without showing that the employer intended the adverse impact to come about. A minority of courts, however, have limited the reach of the disparate impact theory; these courts allow an employee to challenge "objective" criteria such as height and weight cutoffs or diploma requirements, but not to contest subjective or discretionary criteria such as evaluations by superiors or interviewers. This limitation is unjustified both because it thwarts congressional intent as expressed during the 1972 proceedings to amend Title VII, and because it overestimates the severity of the burdens imposed on employers by Title VII challenges to the disparate impact of subjective employment criteria.

\section{The Development of the Disparate Impact Test}

A. The Distinction Between the "Disparate Treatment" and "Disparate Impact" Theories

Title VII of the Civil Rights Act of 1964, as amended in 1972, declares it

an unlawful employment practice for an employer-(1) to fail or refuse to hire or to discharge any individual, or otherwise to discriminate against any individual with respect to his compensation, terms, conditions, or privileges of employment, be- 
cause of such individual's race, color, religion, sex, or national origin; or (2) to limit, segregate, or classify his employees or applicants for employment in any way which would deprive or tend to deprive any individual of employment opportunities or otherwise adversely affect his status as an employee, because of such individual's race, color, religion, sex, or national origin. ${ }^{1}$

This statute prohibits two distinct practices: (1) discrimination and (2) the use of criteria that "tend to deprive any individual" of employment "because of" race or other forbidden classifications. Accordingly, federal courts have interpreted Title VII to create two causes of action, each distinct and entailing proof of different elements. ${ }^{2}$ In a "disparate treatment" action, the plaintiff establishes a prima facie case by showing intentional discrimination. The leading case employing the disparate treatment theory is McDonnell Douglas Corp. v. Green, ${ }^{3}$ in which a black employee who had been fired because of his participation in illegal civil rights protests against his employer applied for and was denied reinstatement. The Supreme Court noted that an employee could establish a prima facie case of intentional racial discrimination

by showing (i) that he belongs to a racial minority; (ii) that he applied and was qualified for a job for which the employer was seeking applicants; (iii) that, despite his qualifications, he was rejected; and (iv) that, after his rejection, the position remained open and the employer continued to seek applicants from persons of complainant's qualifications. . . . The burden then must shift to the employer to articulate some legitimate, nondiscriminatory reason for the employee's rejection. . . . [The plaintiff must then] be afforded a fair opportunity to show that [the employer's] stated reason for [plaintiff's] rejection was in fact pretext. ${ }^{4}$

It is the second type of action, which challenges the "disparate impact" of an employment practice, that some courts have permitted only when the practice is "objective." To establish a prima facie case here, the plaintiff must allege that a particular employ-

1 Title VII of the Civil Rights Act of 1964, § 703(a), 42 U.S.C. $\S 2000 \mathrm{e}-2$ (a) (1982).

2 Texas Dept. of Community Affairs v. Burdine, 450 U.S. 248, 252 n.5 (1981); Teamsters v. United States, 431 U.S. 324, 335-36 n.15 (1977).

3411 U.S. 792 (1973).

1 Id. at 802-04. 
ment practice ${ }^{\sigma}$ has a discriminatory effect on members of a protected class. Proof of discriminatory intent is not required. The employer then has the burden either to rebut the showing of discriminatory effect or to demonstrate the necessity of the challenged practice.

The disparate impact framework was established in the seminal case of Griggs $v$. Duke Power $\mathrm{Co}^{6}{ }^{6}$ There, the employer required satisfactory scores on two professionally prepared aptitude tests purporting to measure general intelligence and mechanical ability, and in some cases required a high school diploma, as prerequisites for either initial hiring or transfer into more desirable and higher-paying jobs. The Fourth Circuit upheld dismissal of the suit because the plaintiff had made "no showing of a racial purpose or invidious intent." The Supreme Court reversed, holding that "good intent or absence of discriminatory intent does not redeem employment procedures or testing mechanisms that operate as 'built-in headwinds' for minority groups and are unrelated to measuring job capability. . . . Congress directed the thrust of the Act to the consequences of employment practices, not simply the motivation." Prescribing the sequence of proof in such a case, the Court observed: "The Act proscribes not only overt discrimination but also practices that are fair in form, but discriminatory in operation. The touchstone is business necessity. If an employment practice which operates to exclude Negroes cannot be shown to be related to job performance, the practice is prohibited."

- Whether several practices may be challenged in a single disparate impact action is a matter of disagreement among courts that have considered the question, as discussed below.

- 401 U.S. 424 (1971).

7 Id. at $428,429$.

Id. at 432 (emphasis in original).

- Id. at 431. See also Connecticut v. Teal, 457 U.S. 440, 446 (1982); Albemarle Paper Co. v. Moody, 422 U.S. 405, 431 (1975) ("[D]iscriminatory tests are impermissible unless shown, by professionally acceptable methods, to be 'predictive of or significantly correlated with important elements of work behavior which comprise or are relevant to the job or jobs for which candidates are being evaluated.'" The process of showing such a correlation is known as "validation" and is subject to detailed regulation by the Equal Employment Opportunity Commission ("EEOC"), the Civil Service Commission, and the Departments of Labor and Justice. See 29 C.F.R. $\$ 1607$ (1986).

Even before Griggs, lower federal courts had found violations of Title VII based on what is now called disparate impact. See, e.g., Jones v. Lee Way Motor Freight, Inc., 431 F.2d 245 (10th Cir. 1971) (refusal to transfer city truck drivers to over-the-road work); U.S. v. Bethlehem Steel, 446 F.2d 652, 655 (2d Cir. 1971) (failure to use objective hiring procedures). Similar cases are catalogued, and denounced as inconsistent with the intent of the 88th Congress, which enacted Title VII, in Michael Evan Gold, Griggs' Folly: An Essay on the Theory, Problems, and Origin of the Adverse Impact Definition of Employment Discrimination and a Recommendation for Reform, 7 Indus. Relations L. J. 429,479 n.170 
Thus, unlike a disparate treatment suit, which challenges an employment decision on the ground that it was impermissibly motivated, a disparate impact suit attacks the process by which the challenged decision was reached. In addition, an employer cannot defend the disparate impact of a particular practice by showing that the impact of the employment process as a whole was not discriminatory; a racially balanced "bottom line," in other words, will not do. ${ }^{10}$

\section{B. The Increased Significance of the Disparate Impact Theory: Burdine}

With its 1981 decision in Texas Dept. of Community Affairs $v$. Burdine, ${ }^{11}$ the Supreme Court altered the terrain of Title VII litigation. By reducing the evidentiary burden on defendants in disparate treatment cases, the Court made the alternative theory of disparate impact comparatively more attractive to plaintiffs.

In Burdine, a female employee alleged that she had been de-

(1985).

10 Teal, 457 U.S. at 450 . Just how disproportionate the impact must be is an unsettled question. There is an immense literature on the use of statistical evidence in discrimination cases. See David C. Baldus and James W. L. Cole, Statistical Proof of Discrimination (1980 and 1986 Supp.), and its lengthy bibliography.

The relevant EEOC guidelines apply a rule of thumb known as the "four-fifths rule": "A selection rate for any race, sex or ethnic group which is less than four fifths (4/5) (or eighty percent) of the rate for the group with the highest rate will generally be regarded by the Federal enforcement agencies as evidence of adverse impact, while a rate greater than 80 percent will generally not be regarded by Federal enforcement agencies as evidence of adverse impact." 29 C.F.R. \& 1607.4(D) (1986).

See also Elaine W. Shoben, Differential Pass-Fail Rates in Employment Testing: Statistical Proof Under Title VII, 91 Harv. L. Rev. 793 (1978) (suggesting adoption of a more accurate test, based on standard deviations from a hypothetical mean, to determine the probability that a difference between outcomes of the same test on two groups was produced by chance).

Many courts faced with disparate impact claims have applied the "two to three standard deviations" test, adopted by the Supreme Court as a standard of statistical significance in Castaneda v. Partida, 430 U.S. 482, 496-97 n.17 (1977) (selection for grand jury duty), and Hazelwood School District v. United States, 433 U.S. 299, 311-12 n.17 (1977) (employment discrimination action). For applications of this test in the courts of appeals, see Maddox v. Claytor, 764 F.2d 1539, 1551-52 \& n.13 (11th Cir. 1985); Segar v. Smith, 738 F.2d 1249,1282 (D.C. Cir. 1984). This test measures the probability that a disparity was caused by chance; "in a case where a disparity is larger than 2 standard errors, fewer than 5 percent of the disparities in a random system would be that large, and if the disparity exceeded 3 standard errors we would know that fewer than 1 percent of random selections would result in larger disparities." Baldus and Cole, Statistical Proof $\S 9.03$ at 2.97 (cited in this note). Though subject to criticism, see id. $\S 9.03$ at $294-97$, and Supp. $\S 9.03$ at $118-23$, the staying power of this approach in the federal courts suggests that it has struck a useful balance between technical accuracy and comprehensibility to mathematical laypersons.

11450 U.S. 248 (1981). 
nied a promotion, and then fired, because of her sex. The promotion had gone to a man who, according to the plaintiff, was no better qualified than she. The Fifth Circuit held that "the defendant in a Title VII case bears the burden of proving by a preponderance of the evidence the existence of legitimate nondiscriminatory reasons for the employment action and .... also must prove by objective evidence that those hired or promoted were better qualified than the plaintiff." ${ }^{21}$ A unanimous Supreme Court reversed, holding that to rebut a prima facie case of disparate treatment, the employer need only "raise[] a genuine issue of fact as to whether it discriminated against the plaintiff."13 To do this, he need only "articulate[] lawful reasons for the action . . . [by] produc[ing] admissible evidence which would allow the trier of fact rationally to conclude that the employment decision had not been motivated by discriminatory animus."14

Though the Court remained confident that its framework would still permit a "plaintiff meriting relief to demonstrate intentional discrimination," 15 Burdine made it much easier for employers to rebut charges of disparate treatment. Except where the defendant employer does not or cannot even "articulate" a nondiscriminatory justification for the action, the plaintiff in a disparate treatment case eventually must show by a preponderance of the evidence that the defendant's asserted reason is a mere pretext. ${ }^{16}$ An exhaustive survey of employment discrimination actions concludes that the great majority of disparate treatment cases turn on the issue of pretext. ${ }^{17}$ In order to prove that an employer's justification is a pretext for discrimination, a plaintiff can offer evidence such as a history of racial remarks and abuses, an unlikely paper trail, or an even unlikelier "confession."18 Without such evidence, she must demonstrate "that in a comparable factual situation persons in a different protected group were treated more fa-

12 See id. at 252 (emphasis added).

1s Id. at 254-55 (footnote omitted).

14 Id. at 257.

1s Id. at 258. The primary source of the court's confidence was that a plaintiff has access to the EEOC's report on its investigation of her complaint. Id. While this may facilitate her discovery, it has no bearing on the burden of proof that she will have to sustain. The fact that the defendant "nevertheless retains an incentive to persuade the trier of fact that the employment decision was lawful," id., is equally irrelevant to the plaintiff's increased burden of proof.

16 Id. at 256.

17 Barbara Lindemann Schlei and Paul Grossman, Employment Discrimination Law 1317 (2d ed. 1983).

${ }^{18}$ As in Davis v. Passman, 442 U.S. 228, 230-31 n.3 (1979). 
vorably, or that the defendant departed from its normal policies."19 Such evidence requires statistical analysis not just of one group, but of two, thus magnifying the plaintiff's difficulties. As a result of this increase in the burden on plaintiffs bringing disparate treatment cases, the disparate impact action has become much more attractive.

\section{The Issue: Subjective Criteria and the Disparate Impact Theory}

In disparate treatment actions, courts sometimes treat an employer's use of a subjective employment practice-for example, a system in which supervisors make discretionary promotion decisions-as evidence of discriminatory intent, since its use increases the "opportunit[ies] for unlawful discrimination." In contrast, disparate impact actions, in which the plaintiff challenges the mechanism of decision rather than the decision itself, originally developed in cases involving so-called "objective" requirements such as a "general intelligence" or "aptitude" test," a high school diploma requirement, ${ }^{22}$ or a height and weight cutoff. ${ }^{23}$ In recent years, however, employees have challenged the disparate impact of employment decisions based on the use of subjective factors, such as the preferences of supervisors or interviewers.

Subjective employment practices that have a disparate impact may take many forms. For example, an employer might use a "socalled 'eyeball' test" 24 to select applicants for a job requiring physical strength, with the result that male supervisors might tend systematically to underestimate the strength of female applicants. Another frequently challenged practice, sometimes referred to as "grapevine hiring," is to announce job openings only to members of the current workforce. Persons hired under this procedure are likely to be friends of, and members of the same ethnic group as, the current employees. ${ }^{25} \mathrm{~A}$ similiar practice is the allocation of on-

18 Schlei and Grossman, Employment Discrimination at 1314 (footnote omitted).

2o Bauer v. Bailar, 647 F.2d. 1037, 1046 (10th Cir. 1981). The strength of this inference may depend on the other evidence in the case. See Burrus v. United Telephone Co. of Kansas, Inc., 683 F.2d 339, 342 (10th Cir. 1982); O’Brien v. Sky Chefs, Inc., 670 F.2d 864, 866 (9th Cir. 1982); Stewart v. General Motors Corp., 542 F.2d 445, 450-51 (7th Cir. 1976).

${ }^{21}$ Griggs, 401 U.S. at 429; Teal, 457 U.S. at 443; Albemarle Paper, 422 U.S. at 427.

${ }^{22}$ Griggs, 401 U.S. at 427.

${ }^{23}$ Dothard v. Rawlinson, 433 U.S. 321, 323-24 (1977). 1982).

${ }^{24}$ See, e.g., E.E.O.C. v. Spokane Concrete Products, 534 F.Supp. 518, 523 (E.D. Wash.

${ }^{25}$ See, e.g., Lasso v. Woodmen of World Life Ins. Co., Inc., 741 F.2d 1241, 1243 (10th 
the-job training opportunities in a subjective fashion, based on such open-ended criteria as "the ability of the individual to perform his work, his ability to get along with people, [and] leadership ability."26

The plaintiff's challenge may be quite broad, encompassing the employer's entire hiring or promotion process. The process may "rely heavily on subjective determinations," on stated criteria but permit the employer's decision maker to identify new criteria and assign to them any relative weight she chooses in each case. ${ }^{28}$ An example of this type of discretionary determination is the university tenure system: because most applicants are "eligible" in the sense of having the requisite academic degrees, years of service, and so forth, the final decision often is made solely on the basis of wholly subjective considerations. ${ }^{29}$ Some courts also have recognized that a failure to use objective, measurable criteria is itself a subjective practice that can be challenged without further specification. ${ }^{30}$ In such cases, the process itself is challenged because it operates as a "built-in headwind"31 for a protected group.

Since 1981, the federal courts of appeals have disagreed about whether such disparate impact challenges to subjective employment practices should be permitted. The Sixth, Seventh, Ninth, Eleventh, and D.C. Circuits have allowed such actions; ${ }^{32}$ the Fourth has not; ${ }^{33}$ and the Fifth, Eighth, and Tenth Circuits are

Cir. 1984); Barnett v. W.T. Grant Company, 518 F.2d 543, 547 (4th Cir. 1975); Brown v. Gaston County Dyeing Machine Company, 457 F.2d 1377, 1383 (4th Cir. 1972); E.E.O.C. v. Chicago Miniature Lamp Works, 622 F.Supp. 1281, 1288 (N.D. Ill. 1985); Ingram v. Madison Square Garden Ctr., Inc., 482 F.Supp. 414, 520-21 (S.D.N.Y. 1979).

${ }^{28}$ Muller v. United States Steel Corporation, 509 F.2d 923, 924 (10th Cir. 1975) (describing criteria useful to foremen).

${ }^{27}$ Williams v. Colorado Springs, Colo. Sch. Dist., 641 F.2d 835, 842 (10th Cir. 1981).

28 Hung Ping Wang v. Hoffman, 694 F.2d 1146, 1147 (9th Cir. 1982).

29 See, e.g., Zahorik v. Cornell University, 729 F.2d 85, 96 (2d Cir. 1984), and Peters v. Middlebury College, 409 F.Supp. 857 (D. Vt. 1976), in which the employers successfully rebutted charges that subjective criteria had disparate impact.

so For example, in Atonio v. Wards Cove Packing Co., Inc., 810 F.2d 1477, 1481 (9th Cir. 1987), the court recognized that the "crux" of a valid complaint could be "the lack of well-defined criteria," as well as specific, identifiable subjective criteria like "grapevine" hiring and promotion practices.

s1 See Griggs, 401 U.S. at 432.

32 Rowe v. Cleveland Pneumatic Co., Numerical Control, 690 F.2d 88, 92 (6th Cir. 1982); Regner v. City of Chicago, 789 F.2d 534, 537 (7th Cir. 1986); Stewart, 542 F.2d at 450; Atonio, 810 F.2d at 1478, 1480, 1489 n.2 (9th Cir. 1987) (listing cases); Griffin v. Carlin, 755 F.2d 1516, 1523-25 (11th Cir. 1985); Maddox, 764 F.2d at 1548, Segar, 738 F.2d at 1266.

33 E.E.O.C. v. Federal Reserve Bank of Richmond, 698 F.2d 633, 639 (4th Cir. 1983), rev'd on other grounds as Cooper v. Federal Reserve Bank of Richmond, 467 U.S. 867 
split internally. ${ }^{34}$ Most courts that have disallowed such actions have based the restriction on considerations of fairness to employers; others have simply refused, without explanation, to permit disparate impact actions where they see the facts of the case as too different from those in Griggs. Only a few courts have considered the legislative intent of Title VII, the interests Title VII is meant to serve, and the chances of serving them by application of the disparate impact theory to the particular case. ${ }^{35}$

The leading case holding that disparate impact suits may not contest subjective employment practices, Pouncy v. Prudential Ins. Co. of America ${ }^{36}$ involved both class and individual challenges to Prudential's promotion practices. Pouncy, a black man, asserted that he had been passed over for promotion in favor of a white woman and that Prudential discriminated against blacks as a class in promotion decisions. In his class action, Pouncy presented statistical evidence indicating substantial discrepancies in salaries and promotion rates for black and white employees over a five-year period. He claimed that these disparities resulted from three employment practices: the failure to post notices of job vacancies, suggesting a reliance on "grapevine" hiring procedures; the structure of levels of employment in the organization, tending to hinder promotion from the lowest ranks, where blacks were concentrated; and the "use of subjective criteria in employee performance evaluations." 37

The Fifth Circuit held that the class action claims could not proceed on a disparate impact theory, primarily because of the problems of proof caused by simultaneous challenges to several

(1984).

${ }^{34}$ Compare Page v. U.S. Industries, Inc., 726 F.2d 1038, 1045-46 (5th Cir. 1984), Pettway v. American Cast Iron Pipe Company, 494 F.2d 211, 221 (5th Cir. 1974), and Rowe, 457 F.2d at 355 (permitting suit), with Vuyanich v. Republic Nat. Bank of Dallas, 723 F.2d 1195, 1202 (5th Cir. 1984), and Cunningham v. Housing Auth. of City of Opelousas, 764 F.2d 1097, 1099 (5th Cir. 1985) (barring suit).

Compare E.E.O.C. v. Rath Packing Co., 787 F.2d 318, 328 (8th Cir. 1986) (permitting suit), with Talley v. United States Postal Service, 720 F.2d 505, 507 (8th Cir. 1983) (barring suit).

Compare Lasso 741 F.2d at 1244 and Rich v. Martin Marietta Corporation, 522 F.2d 333, 348 (10th Cir. 1975) (permitting suit), with Mortensen v. Callaway, 672 F.2d 822, 824 (10th Cir. 1982) (barring suit).

The Second Circuit has not addressed the question squarely. But consider Zahorik, 729 F.2d at 95 (accepting disparate impact theory but recognizing a successful employer defense in the particular case).

ss See Atonio, 810 F.2d at 1482-87.

${ }^{38} 668$ F.2d 795 (5th Cir. 1982).

${ }^{37}$ Id. at 799. 
employment practices:

The discriminatory impact model of proof in an employment discrimination case is not ... the appropriate vehicle from which to launch a wide ranging attack on the cumulative effect of a company's employment practices. . . . Although some courts have used the disparate impact model of proof to challenge multiple employment practices simultaneously . . . this is an incorrect use of the model. The disparate impact model applies only when an employer has instituted a specific procedure . . . that can be shown to have a causal connection to a class based imbalance in the work force. ${ }^{38}$

The court immediately went on to cite a number of cases, including Griggs itself, in which various courts had applied the disparate impact theory to objective employment criteria such as educational attainments, height and weight, participation in a drug maintenance program, credit ratings, and arrest records. ${ }^{39}$

After Pouncy, courts in several circuits began to reject disparate impact actions complaining of subjective employment criteria. ${ }^{10}$ Pouncy concentrated on the arguably unfair burden placed on an employer who is forced to defend several distinct employment criteria simultaneously-a process that may require statistical disaggregation of the effects of those practices, a difficult task. However, courts seized on Pouncy's rejection of the application of the disparate impact theory to subjective criteria, even if challenged individually. According to the Pouncy court:

Pouncy has not shown, nor can he show, that independent of other factors the [subjective] employment practices he challenges have caused the racial imbalance in Prudential's work force. . . . In sum, the nature of the evidence presented by [Pouncy] could not establish a case of employment discrimination based on the disparate impact model.41

These remarks indicate that the court was worried not only about the difficulty of disaggregation where many subjective criteria are challenged at once, but also about the difficulty of proving or disproving the effect of even a single such criterion.

The Pouncy opinion thus makes two principal arguments that

38 Id. at 800 (emphasis added).

39 Id.

10 See notes 33-34.

4688 F.2d at 801-02 (emphasis added). 
disparate impact suits against subjective practices are unworkable. First, because the effect of a subjective practice on a protected group is not predictable, the plaintiff will not be able to prove that its effect was detrimental to that group; second, such a challenge might require employers to justify every stage in a complex hiring or promotion process. These arguments are, respectively, referred to below as the "causation" and the "cumulative effects" arguments.

\section{Title VII's Legitimate Reach}

Pouncy's solicitude for defendants in disparate impact suits impedes the substantive policies behind Title VII. Conventional means of statutory interpretation suggest that Congress strongly favored the disparate impact principle, meaning that not only invidious intentions but also inadvertent discriminatory effects violate the statute's prohibition against "discrimination" and discriminatory classifications. The intent of Congress, as expressed in the legislative history, was to outlaw all employment practices, of whatever sort, that produce a disparate impact without a business necessity. EEOC regulations left undisturbed by Congress for nine years require that the agency challenge such practices. Although Supreme Court interpretations of Title VII have not reached the precise point at issue, the Court's decisions strongly suggest that the statute reaches both subjective and objective practices. Moreover, a contrary rule would perversely encourage employers to make greater use of subjective criteria.

\section{A. The 1972 Amendments: Legislative History and Language}

After eight years' experience with Title VII, Congress in 1972 extensively retooled the statute, and ratified the judicial interpretations of the intervening years. ${ }^{42}$ The legislative history of these amendments discussed and endorsed Griggs, the case that had given Supreme Court sanction to the disparate impact theory. After citing Griggs and quoting eight of its key sentences, ${ }^{43}$ the

12 Equal Employment Opportunity Act of 1972, Pub. L. 92-261, 86 Stat. 109 (1972), codified as 42 U.S.C. $\S 2000$ e et seq. (1982).

${ }^{13}$ Equal Employment Opportunities Enforcement Act of 1971, H.R. Rep. No. 238, 92d Cong., 1st Sess. 21-22 (1971) ("House Report"), reprinted in Legislative History of the Equal Employment Opportunity Act of 1972, Subcomm. on Labor of the Senate Comm. on Labor and Pub. Welfare, 92d Cong., 2d Sess. 81-82 (1972) ("Legislative History"). The quoted sentences are as follows:

The objective of Congress in the enactment of Title VII is plain from the language of 
House Report states: "The provisions of the bill [the 1972 amendments] are fully in accord with the decision of the Court and with the testing guidelines established by the Commission." "44 The important question, of course, is whether in endorsing Griggs, Congress intended to extend the disparate impact theory to subjective criteria, even though the facts of the case itself involved only objective tests.

The decision in Griggs, however, is not easily limited to objective criteria: the opinion makes no mention of any difference between application of the disparate impact theory to subjective and to objective tests. In 1972, moreover, Congress endorsed more than just Griggs. It explicitly accepted other disparate impact cases predating Griggs, ${ }^{45}$ and some of those cases involved subjective employment criteria. ${ }^{46}$ And more generally, the 1972 amendments were intended to expand the scope and force of Title VII, principally by empowering the EEOC to issue judicially enforceable cease and desist orders, whereas under the 1964 Act the EEOC's function had been limited to the promotion of conciliation between employers and employees. ${ }^{47}$ In explaining why the Commission was thought to need greater enforcement power, the House Report noted:

During the preparation and presentation of Title VII of the Civil Rights Act of 1964, employment discrimination tended to be viewed as a series of isolated and distinguishable events,

the statute. It was to achieve equality of employment opportunities and remove barriers that have operated in the past to favor an identifiable group of white employees over other employees. Under the Act, practices, procedures, or tests neutral on their face, and even neutral in terms of intent cannot be maintained if they operate to "freeze" the status quo of prior discriminatory practices. . . . Congress has now provided that tests or criteria for employment or promotion may not provide equality of opportunity only in the sense of the fabled offer of milk for the stork and the fox. On the contrary, Congress has now required that the posture and condition of the job seeker be taken into account. . . . The Act proscribes not only overt discrimination but also practices that are fair in form but discriminatory in operation. The touchstone is business necessity. If an employment practice which excludes Negroes cannot be shown to be related to job performance, the practice is prohibited.

These passages appear in Griggs, 401 U.S. at 429-30, 431.

"House Report at 22, reprinted in Legislative History at 82 (cited in note 43).

45 See 118 Cong. Rec. at 7166 and 7564 (1972), in which the section-by-section analysis of the 1972 amendment submitted to Congress expressly states that existing case law is to govern areas not explicitly addressed in the amendments. The Supreme Court recognized this fact in Teal, 457 U.S. at 447 n.8, and lower courts have done the same, Atonio, 810 F.2d at $\mathbf{1 4 8 2}$.

18 See cases and commentary discussed in the second paragraph of note 9.

4 Compare generally Pub. L. 92-261, 86 Stat. 109 (1972 amendments) with Pub. L. 88352, 78 Stat. 258 (1964 enactment). 
due, for the most part, to ill-will on the part of some identifiable individual or organization. It was thought that a scheme which stressed conciliation rather than compulsory processes would be more appropriate for the resolution of this essentially "human" problem. . . . Employment discrimination, as we know today, is a far more complex and pervasive phenomenon. Experts familiar with the subject [now] generally describe the problem in terms of "systems" and "effects" rather than simply intentional wrongs. . . . The forms and incidents of discrimination which the Commission is required to treat are increasingly complex. ${ }^{48}$

Thus Congress, by recognizing explicitly that the evil of discrimination may be unintentional, powerfully affirmed that all actions-intentional and unintentional - that operate to discriminate are within Title VII's prohibition. Congress intended to prohibit any classification not required by business necessity if it abridges equal employment opportunity for any group protected by the statute. The practices struck down in Griggs fit this description, but so may practices such as "grapevine hiring," the "eyeball test" of strength, and subjective tenure decisions in colleges. There is no suggestion either in the 1972 legislative history or in the decisions ratified by the 1972 amendments that the rule in Griggs should be applied only to employment practices which happen, like those challenged in Griggs, to be objective. ${ }^{49}$

A careful reading of the 1972 amendments themselves also supports the view that Title VII reaches subjective employment criteria that have a disparate impact on protected groups. The pertinent provision states: "[N]or shall it be an unlawful employment practice for an employer to give and to act upon the results of any professionally developed ability test provided that such test . . . is not designed, intended, or used to discriminate." Uno Unless the itali-

48 House Report at 8, reprinted in Legislative History at 68 (cited in note 43 ). Substantially similar language appears in Equal Employment Opportunities Enforcement Act of 1971, S. Rep. No. 415, 92d Cong., Ist Sess. 5 (1971) ("Senate Report"), reprinted in Legislative History at 414 .

40 Some commentators have denounced Pouncy and the cases following it as deliberate efforts to evade or undermine the principle that Title VII condemns effects as well as intentions that are discriminatory. See Cindy Helfand and John de J. Pemberton, The Continuing Vitality of Title VII Disparate Impact Analysis, 36 Mercer L. Rev. 939 (1985); Paulette M. Caldwell, Reaffirming the Disproportionate Effects Standard of Liability in Title VII Litigation, 46 U. Pitt. L. Rev. 555 (1985). Neither article, however, addresses in any detail the specific problem of disparate impact challenges to subjective practices.

so 42 U.S.C. $\$ 2000 \mathrm{e}-2(\mathrm{~h})$ (1982) (emphasis added). 
cized phrase is meant to bring within the proviso unintentional discriminatory effects, it has no meaning at all that is not already supplied by the word "intentional." And while the statute refers only to "professionally developed" ability tests, such tests can be subjective as well as objective-psychological stress response tests, for example.

Thus, the legislative history and language of the 1972 amendments manifest Congress's unequivocal denunciation of employment practices that have a disparate, even if inadvertent, effect on groups protected by Title VII. And nothing in the history or language of these amendments suggests that this condemnation was limited to objective practices.

\section{B. EEOC Regulations}

The regulations promulgated by the EEOC, the agency charged with enforcing Title VII, ${ }^{51}$ prohibit both subjective and objective employment practices that have a disparate impact. Section 3(A) of the Uniform Guidelines on Employee Selection Procedures reads in part: "The use of any selection procedure which has an adverse impact on the hiring, promotion, or other employment or membership opportunities of members of any race, sex, or ethnic group will be considered to be discriminatory and inconsistent with these guidelines, unless the procedure has been validated in accordance with these guidelines." "Selection procedure" is defined to include "the full range of assessment techniques from [objective] requirements through informal or casual interviews and unscored application forms." "s3 The Guidelines also specify that "[w] hen an [unvalidated] informal or unscored selection procedure which has an adverse impact is utilized, the user should eliminate the adverse impact, or modify the procedure to one which is a formal, scored or quantified measure or combination of measures and

s1 See Griffin v. Carlin, 755 F.2d 1516, 1525 (11th Cir. 1985). The Supreme Court frequently has relied heavily on EEOC regulations in its interpretations of Title VII. See, e.g., Local Number 93 v. City of Cleveland, 106 S.Ct. 3063, 3073 (1986); Albemarle Paper, 422 U.S. at 431; Griggs, 401 U.S. at 433; Phillips v. Martin Marietta Corp., 400 U.S. 542, 545 (1971) (Marshall, concurring).

But see General Electric Co. v. Gilbert, 429 U.S. 125, 141 (1976) ("Congress, in enacting Title VII, did not confer upon the EEOC authority to promulgate rules or regulations pursuant to that Title. . . . [Therefore,] courts properly may accord less weight to such guidelines than to administrative regulations which Congress has declared shall have the force of law.") (footnote and citations omitted).

${ }_{32} 29$ C.F.R. $\$ 1607.3(\mathrm{~A})$ (1986) (emphasis supplied).

s3 Id. § 1607.3(Q). 
then validate the procedure in accord with these guidelines, or otherwise justify continued use of the procedure in accord with Federal law." "54 These regulations demonstrate clearly the EEOC's intention to eliminate subjective, as well as objective, employment procedures that have a disparate impact.

\section{Perverse Incentives}

In general, a refusal to condemn subjective employment criteria that impair the employment opportunities of protected groups would create incentives that would flout the intent of Title VII. In a jurisdiction where such suits are forbidden, employers have an incentive to adopt subjective practices and eliminate existing objective methods of evaluation. In such a jurisdiction, an employer can immunize his hiring process from disparate impact suits by, for example, replacing objective tests of strength with "eyeball tests." A female applicant foreclosed from using the disparate impact theory to challenge a decision under such a subjective system is relegated to the disparate treatment theory, and thus she must prove the additional element of discriminatory intent by making the difficult showing that the defendant's justification was pretextual. Those employers intending to discriminate can do so more easily, while even those without bad intentions will tend to shy away from objective criteria whose impact might later be attacked. ${ }^{\mathrm{s}}$

\section{The Relevance of Furnco}

The Supreme Court's pronouncements are, of course, also critical in identifying the scope of a federal statute. In its Title VII decisions, the Court has never held that disparate impact challenges could not be based on subjective criteria. In Furnco Construction Corp. v. Waters, ${ }^{56}$ however, decided before Burdine and Pouncy, the Court suggested in dicta that the disparate impact theory applied only to the employment practices that it had been used to challenge up to that time. In Furnco, the defendant hired only workers from a list of those with whom he was acquainted and whom he knew to be sufficiently skilled. Eight unsuccessful black applicants sued Furnco under Title VII, alleging that they had not been hired or that they were hired later than they would have been

\footnotetext{
54 Id. $\S 1607.6(\mathrm{~B})(1)$.

ss See Griffin, 755 F.2d at 1525 .

sв 438 U.S. 567 (1978).
} 
without this "grapevine" hiring system.

Furnco offered two defenses. First, it argued that the practice did not have a disparate impact, since a worker who was not on the superintendent's list would be turned away whether he was white or black; moreover, the proportion of black bricklayers ultimately hired was greater than the proportion of blacks in the local workforce. Second, Furnco offered a "nondiscriminatory reason" for the practice; it claimed that because on-site training was neither economical nor safe, its reliance on prior experience with particular applicants was the only practical way for it to make hiring decisions. ${ }^{57}$ After a bench trial, the district court found for the defendant.

In a passage not notable for clarity, the Seventh Circuit rejected the defendant's argument that the practice did not have a disparate impact. An employer could not, the court decided, defend against a combined disparate treatment and disparate impact claim by observing that the challenged practice had no disparate impact on the workforce as a whole, even including those workers who had never applied. Instead, the relevant comparison, because of the disparate treatment allegations, was between the bricklayers who had applied and those who had been hired. ${ }^{58}$ The court did not even ask whether the plaintiff's case might, in some manner, appropriately make use of the disparate impact theory.

Furnco appealed to the Supreme Court, which remanded the disparate treatment claim after clarifying the standards applicable to the employer's "“articulat[ion of] some legitimate, nondiscriminatory reason for the employee's rejection," "58 as established by McDonnell Douglas. The Court dealt with the defendant's first, "no disparate impact" argument in a single sentence: "We agree

${ }^{87}$ Waters v. Furnco Const. Corp., 551 F.2d 1085, 1089, 1088 (7th Cir. 1977) (discussing the proceedings in the district court, which are not reported).

sB The court explained:

As we understand the Griggs principle, it provides a method for establishing the presence of discrimination where application of a test to a group of employees or applicants results in a proportionally higher rate of rejection of members of a minority group. Here the reliance upon the superintendent's recollection of bricklayers he considered competent was not a test or device for comparing the members of a group of prospective employees, for there was no defined group. Defendant appears to be treating its reliance on the list as such a device, and the entire body of bricklayers in the area as the group under consideration. Defendant seems to be turning the Griggs principle around, and making it establish absence of discrimination because the group employed by it has a higher percentage of minority members than does the entire relevant labor force.

Id. at 1089.

s9 Furnco, 438 U.S. at 576-78, quoting McDonnell Douglas, 411 U.S. at 802. 
with the Court of Appeals that the proper approach was the analysis contained in McDonnell Douglas." In a footnote, the Court noted that Furnco "did not involve employment tests, which we dealt with in [Griggs] and in [Albemarle Paper], or particularized requirements such as the height and weight specifications considered in [Dothard], and it was not a 'pattern or practice' case like [Teamsters]." "' The Court thus intimated that a plaintiff must challenge tests or requirements similar to those in the cited cases in order to come under the rubric of Griggs. ${ }^{61}$ Justice Marshall, joined by Justice Brennan, dissented from this part of Furnco, correctly noting that the majority purported to affirm the Court of Appeals on an issue that it had not even addressed: whether disparate impact theory was applicable to the plaintiffs' case. ${ }^{62}$

If the Court meant Furnco to foreclose disparate impact challenges to subjective practices, it expressed its wishes only in dictum, since the issue had not arisen below. In fact, perhaps the best assessment of the Furnco footnote is that it is too offhand and Delphic to be accorded much weight. As the concurring judges in Atonio remarked, "[we] do not think it is useful to search at length for an explanation for the Furnco result the Court declined to give us."63 That the controversy surrounding this question remains alive nine years later shows that lower federal courts have not treated Furnco as establishing that disparate impact cases must involve only the type of practices enumerated by the Court. In fact, the majority view is that Furnco did not limit Griggs to objective criteria in this manner. ${ }^{64}$

\section{Outlawing Discriminatory, Subjective Employment Criteria: The Burden on Employers}

Courts that have rejected disparate impact challenges to subjective practices contend that such suits would intolerably burden employers. These arguments reflect a variety of misunderstandings about the burden of proof in the disparate impact context. The Pouncy opinion, which is often cited for the proposition that the disparate impact theöry applies only to objective employment

${ }^{60}$ Furnco. 438 U.S. at 575, 575 n.7.

${ }^{61}$ One treatise erroneously describes the Court's footnote as the "holding" of Furnco. Arthur Larson and Lex K. Larson, 3 Employment Discrimination $\S 76.32$ at 15-85 (1986).

${ }^{62}$ Furnco, 438 U.S. at 583-85 (Marshall, dissenting).

es 810 F.2d at 1493 n.5.

64 See cases cited in note 32 . 
practices, ${ }^{65}$ employs two principal arguments: "causation" and "cumulative effects." In addition, some courts are worried that disparate impact suits against subjective practices would impose "strict liability" under Title VII because even an employer with benign intentions might be liable if its subjective practices have a disparate impact.

\section{A. Proof of Causation}

Pouncy suggests that no disparate impact challenge to a subjective employment criterion could proceed, because a plaintiff could not show that the

employment practices that he has identified have caused the racial imbalance in [the employer's] work force. . . . Aptitude tests, height and weight requirements, and similar selection criteria all may be shown to affect one class of employees more harshly than another by controlling for the impact of the employment practice on one class in the employer's work force so that it can be measured. . . . By contrast, Pouncy has not shown, nor can he show, that independent of other factors the employment practices he challenges have caused the racial imbalance in Prudential's work force. ${ }^{66}$

Pouncy's first claim is correct as far as it goes. The effect of a nondiscretionary criterion can be inferred from statistical evidence, or even from common knowledge; it need not be shown directly. For example, in Dothard v. Rawlinson, the plaintiffs demonstrated that a height requirement had a disparate impact on women by referring to statistics describing the height of men and women in the population at large, on the premise that the height of women who applied for the jobs in question did not vary significantly from the height of women in general. ${ }^{67}$ The Pouncy causation argument says that, unless it is possible to show the impact of the practice by external, statistical means that refer to a representative sample of the protected group as a whole, disparate impact theory is

6s See, e.g., E.E.O.C. v. Federal Reserve Bank of Richmond, 698 F.2d 633, 659 (4th Cir. 1983); Pegues v. Mississippi State Employment Serv., 699 F.2d 760, 765 (5th Cir. 1983); Pope v. City of Hickory, N.C., 679 F.2d 20, 22 (4th Cir. 1982); Watson v. Fort Worth Bank \& Trust, 798 F.2d 791, 797 (5th Cir. 1986); Lewis v. N.L.R.B., 750 F.2d 1266, 1271 (5th Cir. 1985); Carroll v. Sears, Roebuck \& Co., 708 F.2d 183, 188 (5th Cir. 1983); Carpenter v. Stephen F. Austin State University, 706 F.2d 608, 620 (5th Cir. 1983).

Bs Pouncy, 668 F.2d at 801. Similar reasoning appears in Carroll, 708 F.2d at 189, and Pope, 679 F.2d at 22.

6733 U.S. 321,330 (1977). 
inapplicable.

This refusal to apply Title VII to a subjective practice operating as a "headwind" for minorities serves no purpose. The disproportionate impact of a practice can be shown with equal persuasiveness by other empirical means. If the record shows, for example, that the unreined discretion of a supervisor has led her to choose disproportionately high numbers of white over black candidates for promotion, ${ }^{68}$ then this discretion is operating in the same way as did the diploma requirement in Griggs, and causation is proved; as Griggs held, the motivation behind the discriminatory impact is not in issue. As the legislative history makes clear, a prima facie violation of Title VII occurs when an "institutional device" disproportionately impedes the employment progress of members of a protected class. It must be open to plaintiffs to show that this has in fact happened. The plaintiff need not prove in addition, as Pouncy would require him to do, that the challenged requirement would operate that way in the hands of any employer who applied it; it is up to the employer to show that "business necessity" requires her to use it at all.

\section{B. Cumulative Effects}

Pouncy also suggested that a suit challenging a complex employment procedure would unfairly force the employer to isolate the one practice, whether subjective or objective, which was responsible for the challenged impact. The Pouncy court would not "permit a plaintiff to challenge an entire range of employment practices merely because the employer's work force reflects a racial imbalance that might be causally related to any one or more of several practices."

This argument from "cumulative effects" apparently contemplates a situation in which an employer evaluates applicants on the basis of several criteria, for example, a high school diploma, a height cutoff, a weight cutoff, a score on a job aptitude test, and an interview with a member of the personnel department. Suppose a female plaintiff brings a Title VII suit in which she offers to prove that 50 percent of applicants for these jobs, but only 8 percent of those hired, are female (a statistically significant ratio). She would argue that the employer's overall hiring system operates as an ob-

\footnotetext{
${ }^{68}$ See, e.g., Muller v. United States Steel Corporation, 509 F.2d 923, 924 (10th Cir. 1975).

${ }^{69} 668$ F.2d at 801.
} 
stacle for women. The Pouncy court feared that, in order to defend such a suit, the employer would have to justify all five criteria, most likely through statistical disaggregation of the effects of each criterion, and concluded that the burden of proving causation through this disaggregation process should remain on the plaintiff in the case of subjective criteria. Of course, the difficulty of disaggregation that the court describes in this passage also arises in connection with simultaneous challenges to multiple objective employment criteria. Yet, the court apparently believed that employers were capable of disaggregating the effects of employment criteria where statistics on the effects of such criteria on subgroups of the protected group in the population as a whole were available, as would be the case for objective criteria. This is the crucial distinction: the effects of an objective criterion such as a height requirement can be assessed simply by acquiring statistical data on the height of the protected group as a whole. This makes it possible to separate the effect of the height requirement from, say, that of a simultaneously applied manual dexterity requirement. All that is required is an assumption that those who applied for the job were themselves a representative sample of the protected group. However, with subjective criteria, there is no way to determine the effect of a subjective practice on the protected group as a whole (the problem would be similiar to determining whether all blacks are "friendlier" than all whites), so the employer cannot disaggregate the effects of the challenged practice unless he happens to have a sufficiently large, already-classified sample among his own employees. It may have been recognition of this problem that led the Pouncy court to reject use of a disparate impact theory for all subjective criteria cases, while allowing its use in cases involving objective criteria.

Griggs, and the 1972 Congress, condemned "practices that are fair in form, but discriminatory in operation" and unrelated to job performance. ${ }^{70}$ When an employee shows that an employer's practice is "discriminatory in operation"-that is, that it disproportionately impairs the employment opportunities of a protected group-the employer must show either that there is no such impact or that each of the practices is necessary for other reasons. Where the challenged "practice" is the entire process of decision making, the employer cannot show either of these things without subdividing the process into steps and considering each. Pouncy 
suggests that this is an unfair burden to place on the employer. Indeed, an employer may have difficulty developing meaningful statistics on the effect of each of the five challenged steps if it employs few people or if it has not developed such statistics in the ordinary course of business.

But such an employer will have to isolate the effect of particular practices only if it cannot demonstrate its business necessity. The employer has the option to defend the disparate impact of its hiring process by showing that the five steps outlined above are all necessary to its business. A Title VII suit will never force the employer to consider the potentially complex question of causation, or to perform an elaborate statistical disaggregation, unless it chooses to do so, as it will do only where that option seems easier than defending its practices on grounds of business necessity. This is not to say that an overbroad complaint attempting to force the employer to justify an entire range of employment practices should be allowed; plaintiffs may be required to make more specific allegations. There is no reason, however, to suppose either that all disparate impact challenges to subjective practices are overbroad, or that all overbroad, "cumulative effects" complaints involve subjective practices. All employment decisions, even those seemingly based solely on criteria such as intelligence tests, weight requirements, and the like, embody a subjective decision that those particular tests are appropriate. As the Ninth Circuit observed in Atonio:

Proving business necessity is no more onerous in a case involving subjective practices than one involving objective practices, because in either case the employer is the person with knowledge of what his practices are and why he uses the methods and criteria he does, as well as the person with superior knowledge of precisely how his employment practices affect employees. The burden of proof on the employer is commensurate with the greater burden on the plaintiff [in disparate impact actions involving subjective criteria] to prove impact and to establish the causal connection between the [challenged] practices and the impact. ${ }^{71}$ 


\section{C. "Strict Liability" on Employers}

Some courts have suggested that allowing plaintiffs to bring disparate impact suits against subjective decisions unfairly subjects employers to a kind of strict liability, or liability without malicious intent. ${ }^{72}$ Suppose that a college decides to grant teachers tenure based on a vote of the currently tenured faculty, using subjective criteria only. The vote is subject to review by the dean of the college, who is also to apply subjective criteria; the decision must be "based on his or her independent judgment of the merits of the appointment and the long term interests of the university." The college notices that this process disproportionately promotes men. Two alternatives follow: promote more women or risk being required to justify the disparate impact of the tenure process. It appears that the college is "strictly liable" in that it must choose between potential Title VII liability and promoting more workers of a given sex or race. To some courts, it seems inequitable that hiring or promoting a certain number of members of a particular class should be the only way to avoid liability under the statute. This solicitude for the dilemmas of the employer, however, is misplaced.

First, an employer will find itself in this dilemma only if minority representation in its workforce is grossly disproportionate to that in the applicant pool. The 95 percent confidence level implicit in the two-to-three standard deviation test significantly reduces the likelihood that any employer will find itself subject to Title VII liability "by accident."

Second, even when the employer's subjective discretion has favored one group so disproportionately that the inequity is statistically significant, it must justify not its choices, but rather the incorporation of subjective elements into its system. The college need not, for example, show why its discretion led to particular decisions. It must only show that it is a "business necessity" to exercise such discretion and to give subjective criteria controlling weight. ${ }^{74}$ Indeed, on similar facts, the Zahorik court found that the

72 See, e.g., Atonio, 768 F.2d at 1133, rev'd en banc, 810 F.2d 1477.

7s Somewhat simplified, these are the facts of Zahorik, 729 F.2d 85 . See also Peters, 409 F.Supp. 857.

74 See Segar, 738 F.2d at 1271. Elizabeth Bartholet, Application of Title VII to Jobs in High Places, 95 Harv. L. Rev. 945, 957-58 (1982), notes that the business necessity of a subjective criterion is likely to be judged more leniently in an "upper-level" professional job. However, this does not militate against application of the disparate impact theory to "jobs in high places." The solution to the problem is simply to apply an equally stringent standard of business necessity to subjective evaluations of employees and job applicants in both 
subjective criteria used by Cornell University were "legitimately related to the position of tenured professor." win a disparate impact case against charges of improper use of subjective criteria, by showing that it must use the challenged subjective process.

Finally, the "innocent discriminator," whose intentions are not invidious but whose hiring decisions harm a protected group to a statistically significant extent, is exactly the party that Griggs sought to reach. Liability under Title VII, as Congress has drawn its boundaries, is indeed "strict liability" in the sense that intent is not always an element of a violation. While this has seemed inequitable to some courts, any such inequity is squarely within the contemplation and intent of Congress. Nor does this interpretation require hiring by quota, except insofar as the whole concept of employment discrimination legislation does so. The college can violate Title VII by promoting "too few" women, and the liability can be avoided by promoting more women rather than by proving business necessity. If it promotes more women, it may more closely align itself with the "applicant pool," meet the two-to-three standard deviation test, and thereby eliminate the disparate impact. In so doing, it will satisfy Title VII requirements. But the employer also may satisfy these requirements by demonstrating the business necessity of its practices.

\section{CONCLUSION}

The courts of appeals disagree as to whether a plaintiff may make out a prima facie case under Title VII by showing the disparate impact upon a protected class of a subjective employment practice. Although the disparate impact theory originally developed in challenges to objective employment practices, the 1972 amendments to Title VII endorsed disparate impact suits without any limitation to the facts of early cases. If disparate impact suits could challenge only objective practices, this would encourage employers to protect themselves by switching from objective evaluations of their employees' performance to subjective evaluations. The courts should not undermine the efforts of Congress by encouraging the practices that present the greatest opportunity for discrimination.

Some courts have argued that such a suit presents intractable 
problems of proof, throws onto employers an intolerable burden of justifying every one of their employment practices, or subjects employers to automatic liability if their workforces are not sufficiently representative of every class protected by Title VII. These fears are illusory. Proof of causation is different when a discretionary decision is in question, but the burden on the defendant is not substantially different from that in any disparate treatment suit. Liability will not follow from an imbalance in the composition of the employer's workforce unless the imbalance results from a subjective practice for which the employer cannot show business necessity.

Christopher Dee 